\title{
Kirkene og
}

Israel

Pengeinnsamling til jødiske bosettere og annen støtte til Israels okkupasjon av Vestbredden, Øst-Jerusalem, Gaza og Golan har fått større oppmerksomhet i det siste. Denne virksomheten - ulovlig etter internasjonal rett - er imidlertid ingen nyhet for dem som har fulgt norske kristne israelvenner over en periode.

Hans Morten Haugen er 1. amanuensis ved Diakonhjemmets Høgskole, og har tidligere arbeidet for Mellomkirkelig råd for Den norske kirke (1996-2002), Norsk senter for menneskerettigheter (2002-05) og Kirkens Nødhjelp (2005-06). 
TEKST: Hans Morten Haugen

ÅRET ER I994, datoen er I2. desember. En større religionsdialogkonferanse med sentrale jødiske, kristne og muslimske ledere fra Israel og det palestinske området holdes to dager etter fredspristildelingen ved Nobelinstituttet, ledet av Mellomkirkelig råd og Norges Kristne Råd. Konferansen gav økt tyngde til et engasjement for en rettferdig fred i Israel/Palestina og for religionsdialog som et redskap for fred. Imidlertid fantes allerede da et norsk kristent engasjement $i$ området som kan spores både 50 og så langt som I50 år tilbake. Palestinerne, både kristne og muslimske, har lenge vært usynlige i dette arbeidet.

Artikkelen vil analysere norske kristne organisasjoner og kirker for å identifisere sentrale skillelinjer mellom disse i deres syn på konflikten mellom israelere og palestinere og analysere deres arbeid til støtte for israelere og palestinere. Først noen begrepsavklaringer:

Kristensionisme: En bevegelse som oppsto tidlig i det I9. århundret. Den har utviklet seg i tråd med de politiske endringene i regionen. Grunnleggende kjennetegn er en sterk støtte til staten Israel som de hevder skal dekke hele Eretz Israel ("Israels Land"), som er gitt jødene av Gud. "Israels Land" oppfattes vanligvis å dekke hele territoriet mellom Jordanelven og Middelhavet, men mange ønsker en langt større utbredelse. Etter I Mos I5,I8 skal "Israels Land" dekke også deler av Egypt, hele Jordan, Libanon, Syria og halve Irak.

Israelvenn: En person eller sammenslutning som er grunnleggende positiv til staten Israel, gjerne ut fra en bibelsk begrunnelse, men uten å nødvendigvis ha en kristensionistisk oppfatning. Vil ofte forsvare den israelske okkupasjonen og okkupasjonspolitikken, siden de mener at dette fremmer Israels sikkerhet.

Kritisk israelvenn: En person eller sammenslutning som ikke ser at Israel har rett til å okkupere i strid med internasjonal rett eller forskjellsbehandle egne borgere, men som samtidig uttrykker støtte til Israel. Disse bygger på en klar folkerettslig linje, i kontrast til dem som mener Bibelens landløfter er det sentrale for å forstå konflikten - og løsningene.

\section{Hva skiller kirkene?}

Som utgangspunkt for analysen ${ }^{\text {I }}$ er det viktig å merke seg at blant norske kristne som andre nord-europeiske kristne fantes et sterkt engasjement for Israel i årene etter Israels etablering. I årene etter I967 har det skjedd en gradvis forskyvning mellom de ulike kirkesamfunn. Karismatiske kirkesamfunn, inspirert av bibelske 
landløfter, har blitt mer tydelige i sin støtte av Israel og av alt Israel foretar seg. Mange legger større vekt på disse landløftene enn på situasjonen til de folkene som rammes som følge av realisering av disse

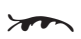

Karismatiske kirkesamfunn, inspirert av bibelske landløfter, har blitt mer tydelige $i$ sin støtte av Israel.

landløftene. Andre kirkesamfunn, i første rekke lederplanet i Den norske kirke, kan forstås å ha beveget seg i retning av et mer kritisk vennskap med Israel, der okkupasjonen oppfattes som et hinder for en rettferdig fred. Vedtaket om "deinvestering” fra selskaper som bidrar til og tjener på den israelske okkupasjonen (se under), er et uttrykk for dette. Samtidig er det opplagt at et så stort og mangfoldig kirkesamfunn som Den norske kirke ikke rommer ett enkelt syn på konflikten. ${ }^{2}$

I en nordisk sammenheng utmerker norske kirkelige organisasjoner seg på tre områder. For det første var Norge tidlig ute med organisert støtte både til misjon blant jøder og økonomisk støtte til palestinerne. For det andre er det ingen andre land som har så mange organisasjoner som er etablert for å støtte staten Israel og jødene. For det tredje er det ingen andre land som har en organisasjon etablert med det formål å samle inn penger for å hjelpe jødene å immigrere til Israel. Det er særlig de siste to som underbygger at norske kristne organisasjoner er med på å understøtte den folkerettsstridige okkupasjonen. Hva gjelder støtte til innvandring til Israel, er dette ikke en direkte støtte til okkupasjo- nen. Aksjonskomiteen Hjelp Jødene Hjem $(\mathrm{HJH})$ har støtte fra flere kirkesamfunn ${ }^{3}$ for å hjelpe jøder med “... å reise til Israel, lette overgangen til et nytt liv og bistå i tilpasning til et nytt hjemland." ${ }^{4} \mathrm{HJH}$ framstiller seg som en politisk og religiøst nøytral organisasjon, men нјн uttrykker seg mer politisk enn både hva organisasjonens opprinnelige mandat tilsier, og hva de forskjellige kirkesamfunnene står for.

Mange kristne holder fast på sin Israelstøtte ut fra en grunnforståelse om at det er fundamentalt galt å kritisere Guds utvalgte folk, basert på spesielle tolkninger av visse bibelvers. ${ }^{5}$ Disse gruppene representerer stadig færre, men er samtidig klare i sin oppfatning om at de handler innenfor det de ser som Guds plan. Generelt gjelder motsetninger disse temaene:

Misjon: Noen kristne organisasjoner ser misjon for jøder som det helt sentrale, mens andre legger vekt på religionsdialog. Noen av de kristensionistiske organisasjonene, som Karmelinstituttet (se under), er mot misjon blant jøder fordi jødene har sin egen frelsesvei. I Den norske kirkes lederplan er misjon blant jøder tonet ned til fordel for dialog de siste årene.

Bibelske landløfter: Kristne organisasjoner som kritiserer staten Israel sin politikk overfor palestinerne, gjennom okkupasjonen og okkupasjonsregimet, opererer med internasjonal lov som styrende for å vurdere israelske myndigheters handlinger, og avviser at bibelske løfter gitt til Israelfolket kan direkte overføres til staten Israel. Andre organisasjoner er etablert med det primære formål å forsvare og "trøste" Israel.

Humanitor innsats: Noen kristne organisasjoner har også fokus på å gi økonomisk støtte til palestinere, inklusive palestinske 
flyktninger. Andre søker å hjelpe fattige jøder, både dem som er bosatt i Israel, og dem man ønsker skal bosette seg der. Slik støtte kan øke motivasjonen til å bosette seg i Israel, og kan også hindre at flere emigrerer fra Israel.

\section{Den Norske Israelsmisjon}

I I844 ble Israels Venner i Stavanger etablert av de samme menneskene som startet det som etter hvert ble Det norske misjonsselskap. Navnet på organisasjonen ble raskt endret til Den Norske Israelsmisjon. Av paragraf $2 \mathrm{i}$ de opprinnelige statuttene kan vi lese: "Denne Forening har et dobbelt Formaal, dels iblant de Christne at vække Kjærlighed til Israel, dels iblandt Israel at virke til Christendommens Fræmme." ${ }^{\prime}$ Paragraf 7 bruker eksplisitt uttrykket "Jødernes Omvendelse".

Arbeidet startet i Sentral- og Øst-Europa. Det var først i 1949 at den første utsending fra Israelsmisjonen faktisk ble sendt til Tel Aviv og etter hvert til Haifa. Israelsmisjonen har etablert virksomhet i tre byer: Tel Aviv (Immanuelkirken), Haifa (Eliaskirken og Ebenezerhjemmet) og Jerusalem (Casparisenteret). Israelsmisjonen har samarbeidet med både Det israelske bibelselskapet og Det lutherske verdensforbund (LWF). En tid stilte også Israelsmisjonen opp i samhandlings- og givermøter for Den palestinske lutherske kirken, ELCJHL, men dette ivaretas nå av Mellomkirkelig råd for Den norske kirke.

Organisasjonen arbeider blant jøder i Øst-Europa, og var blant initiativtakerne til Aksjonskomiteen Hjelp Jødene Hjem, nevnt ovenfor. Israelsmisjonen har uttrykt kritikk over det økende Israel-kritiske engasjementet til spesielt Kirkens Nødhjelp. Samtidig har Israelsmisjonen en rel- ativt balansert holdning til konflikten, men blant medlemmene er nok støtten til staten Israel sterkere enn blant ledelsen. Israelsmisjonen “ $\ldots$ vil arbeide for at den kristne kirke [...] får en bibelsk forståelse for Guds plan og vilje med det jødiske folk ...” Samtidig vil organisasjonen også “... bekjempe anti-palestinske holdninger [...] og forsvare deres rettigheter i henhold til internasjonal rett." ${ }^{\text {10 }}$

Israelsmisjonens motto "For jøde først" viser at mandatet er relativt smalt. Samtidig kan det spørres om Israelsmisjonen har gjort nok for å formidle informasjon om de palestinske kristne til sine norske støttespillere. Fra 2006 samarbeider organisasjonen aktivt med Musalaha, en forsoningsorganisasjon basert i Jerusalem som bringer sammen messianske (Jesustroende) jøder fra Israel og palestinske kristne.

\section{Karmelinstituttet}

Den organisasjonen som sammen med Israelsmisjonen har hatt det lengste norske nærværet i Israel, er Karmelinstituttet. Per Faye-Hansen etablerte organisasjonen i I945.

Karmelinstituttet hevder - kontroversielt nok - at jøder og kristne har ulike veier til frelse. Organisasjonen har opplevd flere splittelser, og to organisasjoner springer direkte ut av Karmelinstituttet. ${ }^{\text {II }}$ Instituttet har gradvis fått mindre betydning som følge av den store økningen i alternative kristensionistiske organisasjoner - nå over 30 i Norge. ${ }^{\mathrm{I2}}$

Typisk for de fleste kristensionistiske organisasjoner er en ignoranse overfor palestinernes historie og situasjon. Videre bekreftes og forsterkes jødenes offerrolle, også i dagens situasjon. Det er disse som 
samler inn penger blant norske kristne til jødiske folkerettsstridige bosetterne i det okkuperte palestinske området, som nylig omtalt i Dagens Næringsliv. ${ }^{\text {I3 }}$

Siden Karmelinstituttet oppfatter at jødene har sin egen vei til frelse, er Karmelinstituttet ikke opptatt av misjon, og de har ikke noe omfattende humanitært arbeid, men er iherdige i sin støtte til staten Israel og dens aksjoner, militære så vel som politiske.

\section{Pinsebevegelsen}

Pinsebevegelsen utmerker seg med å være en sterk, og det man kan kalle ukritisk, Israelsvenn, med organisert virksomhet i 59 år. Slik sett passer Pinsevennene godt til å illustrere strømninger $\mathrm{i}$ det lavkirkelige og frikirkelige Norge. ${ }^{\mathrm{I}}$ Det er viktig å være klar over at pinsebevegelsen ikke er et sterkt sentralisert kirkesamfunn, og det er derfor vanskelig å gi en generell karakteristikk av Pinsevennenes arbeid. Noen pinsemenigheter, sammen med noen baptistmenigheter, inviterer gjerne talspersoner for de jødiske folkerettsstridige bosetterne i det okkuperte palestinske området til sine møter. Andre menigheter bruker israelske flagg som dekorasjon. Pinsebevegelsen karakteriseres av både jødemisjon, humanitært arbeid og politisk støtte til Israel, og mange medlemmer og menigheter er kristensionistiske. Pinsevenner er også de mest aktive kritikerne av Kirkens Nødhjelps arbeid i Israel og i det palestinske området.

Norske Pinsevenners Arbeid i Israel (NPAI) ligger under Feltutvalget for Israel i Pinsevennenes Ytremisjon. Arbeidet er både politisk og sosialt: "Det har aldri i historien vært et palestinsk-arabisk land i dette området. Vi finner det uakseptabelt at
Israel skal tvinges til å avstå landområder til dette formålet. NPAI vil støtte prosjekter hvor vi kan vise Jesu nestekjærlighet, enten det gjelder mot jøder eller arabere." ${ }^{\text {is }}$ Det sies ikke noe om formelle kontakter med palestinske kristne menigheter, selv om det ikke kan utelukkes at slike kontakter finnes uten at de offentliggjøres. Derimot er det tydelig at det legges vekt på landløftene. En reportasje i bladet Sjibbolet fra et besøk ved en ulovlig bosetting sør-øst for Betlehem på den okkuperte Vestbredden viser at NPAI klart støtter jødiske bosettinger: "[Det ble] bedt inderlig for både stedet og det lille samfunnet som vil bevise at Gud holder sine løfter." Bygging av bosettinger medfører tap av palestinsk land og bevegelsesfrihet, og er ett av de viktigste hindrene for fred. Det praktiske arbeidet til N PAI foregår også i bosettingene.

Som eneste rene kirkesamfunn er Pinsebevegelsen også med i Felleskomiteen for Israel. Dette nettverket har fungert fra I988, med II organisasjoner, inklusive Israels Venner på Stortinget. Felleskomiteen er relativt usynlig og har liten innflytelse. Det mest synlige engasjementet de siste årene har vært en aksjon for å hindre Odd Karsten Tveit som NRK-korrespondent.

\section{Kirkens Nødhjelp}

Kirkens Nødhjelp startet sitt arbeid i I947 som en innsamling til internt fordrevne tyskere. Den neste store flyktningstrømmen som utfordret Kirkens Nødhjelp var den palestinske al-nakba ("katastrofen") i I948, da 75 prosent av palestinerne (750.000 personer) flyktet fra Palestina, både som følge av angrep fra sionistiske styrker før staten Israel ble opprettet, og angrep fra disse under deres krig med de 
arabiske nabolandene. Fra og med I950 til i dag har Kirkens Nødhjelp formidlet penger fra norske menigheter til kirkelig arbeid for palestinske flyktninger, både $\mathrm{i}$ Libanon, Jordan, Vestbredden, Gaza og

\section{Typisk for de fleste kristensionistiske} organisasjoner er en ignoranse overfor palestinernes historie og situasjon.

Israel, primært gjennom Middle East Council of Churches og Det lutherske verdensforbund (LWF). Støtten til de palestinske flyktningene er dermed det engasjementet innenfor Kirkens Nødhjelp med lengst varighet. De nye partnerne er i større grad sekulære, både israelske og palestinske, som arbeider med brobygging mellom israelere og palestinere. Sentralt for partnernes arbeid er også at de arbeider aktivt i forhold til menneskerettigheter, både hindring av overgrep og med behandling etter overgrepene.

Sammen med Mellomkirkelig råd, Norges Kristne Råd og Norges KFUK/M står Kirkens Nødhjelp bak Kirkenes Verdensråds økumeniske ledsagerprogram i Norge. ${ }^{17}$ Ledsagerne har ulike funksjoner de tre månedene de er ute. I byer som Hebron eller landsbyer nær jødiske bosettinger i det okkuperte palestinske området, handler arbeidet om å beskytte palestinere mot overgrep fra jødiske folkerettsstridige bosettere. I andre byer, som i Betlehem eller Tulkarem, er arbeidet knyttet å bekjempe bygging av den folkerettsstridige separasjonsmuren, eller arbeid med flyktninger. I Jerusalem prioriteres samarbeid med israelske organisasjoner. Formidlings- oppgavene under og etter oppholdet er viktige.

Kirkens Nødhjelp har tatt mer aktivt stilling i saker som oppleves å ha direkte innvirkning på Kirkens Nødhjelps humanitære oppdrag. Videre legger Kirkens Nødhjelp vekt på en folkerettslig tilnærming til konflikten. Kirkens Nødhjelp har arbeidet med bevisstgiøring av norske kirkeledere, koordinert med Norges Kristne Råd. Ved tre anledninger har Kirkens Nødhjelp holdt markeringer mot byggingen av den folkerettsstridige separasjonsbarrieren. Dette har møtt kritikk, blant annet fra Israelsmisjonen. ${ }^{19}$

\section{Norges Kristelige Studentforbund}

Det hevdes, kanskje med rette, at Norges Kristelige Studentforbund, som er den eldste (I899) og minste kristne studentorganisasjonen, spilte en sentral rolle i å synliggjøre de palestinske kristne i Norge. Sammen med tidligere generalsekretær Trygve Natvig var det israelvenn og KrF-politiker Jon Lilletun (nå avdød) som introduserte Riah Abu al-Assal, daværende anglikansk prest i Nasaret og nåværende biskop i Jerusalem, til norske politikere og kirkeledere. Studentforbundet driver ikke misjon eller humanitært arbeid og bygger klart på folkeretten som styrende for å bygge en rettferdig fred.

Studentforbundets alternative pilegrimsreiser, som primært foregår til palestinske områder og omtales som besøk til de "levende steinene" (palestinske kristne), har samlet en brøkdel av alle dem som reiser fra Norge til Israel og de palestinske områdene årlig. Likevel er det ingen grunn til å underkjenne betydningen av det arbeidet som ble gjort på 8o-tallet for å skape mer nyanserte oppfatninger om palestinere 
innenfor norsk kirkeliv. Norges Kristelige Studentforbund har vært engasjert i dialogarbeid med Det Mosaiske Trossamfunn i Norge i flere år før Den norske kirke formelt etablerte en dialoggruppe.

\section{Mellomkirkelig råd for Den norske kirke}

Mellomkirkelig råd er Den norske kirkes organ for samhandling med andre kirker og religionssamfunn nasjonalt og internasjonalt..20 I 1997 startet Mellomkirkelig råd arbeidet med en omfattende redningsaksjon for LWF-sykehuset på Oljeberget i Øst-Jerusalem, organisert gjennom Stiftelsen Oljeberget. Samme år vedtok Mellomkirkelig råd en Midtøsten-strategi. Denne omtalte både Syria, Libanon, Tyrkia og Egypt. Vekten i oppfølgingen har ligget på Israel og det palestinske området. Kontakten er primært med Den palestinske lutherske kirken. ${ }^{21}$ Borg Bispedømme har ivaretatt kontakten på biskops- og menighetsplan, blant annet giennom en årlig innsamling til palestinske lutherske kirkens skolearbeid med over 2000 elever. $^{22}$

Mye av arbeidet til Mellomkirkelig råd har handlet om å svare på oppfordringer fra Kirkens Verdensråd. Ett eksempel er samarbeidet om Jerusalem-uttalelsen under generalforsamlingen til Kirkens Verdensråd i 1998. Trond Bakkevig, daværende medlem i Kirkens Verdensråd for Den norske kirke, hadde med seg uttalelsen "Jerusalem - en åpen by for alle" som bidrag til arbeidet med resolusjonen under generalforsamlingen. ${ }^{23}$

Et annet eksempel er vedtaket for å få både Opplysningsvesenets Fond og Oljefondet til å trekke seg ut av selskaper som bidrar til og høster gevinst av Israels okkupasjon. Dette bygger på vedtaket fra
Kirkenes Verdensråd i saken "Visse økonomiske tiltak for fred i Israel/Palestina", som sier i den sentrale paragrafen: "Påminner kirker som har investeringsfond at de har muligheten til å gjøre ansvarlig bruk av disse fondene for å støtte en fredelig løsning på konflikten. Økonomisk press, utøvd korrekt og åpent, er en slik mulig handling." ${ }^{24}$ I innledningen til vedtaket sier Mellomkirkelig råd: "Ei oppmoding om de-investeringar er ikkje retta mot Israel generelt, men mot investeringar $\mathrm{i}$ firma som etter avtale med staten Israel driv si verksemd i okkupert område." ${ }^{25}$

Mellomkirkelig råd har over en tiårsperiode utarbeidet et større religionsdialogprosjekt knyttet opp til religiøse insti-

Kristne, ukritiske israelvenner står dessverre i en direkte interessemotsetning til de palestinske kirkene.

tusjoner basert i Jerusalem, blant annet det jødiske rabbinatet, den muslimske shariadomstolen og kirkeledermøtet i Jerusalem. Trond Bakkevig har vært praktisk tilrettelegger. Målet er å skape et fast nettverk av religiøse ledere som kan bringe inn den religiøse dimensjonen i de politiske samtalene, med særlig fokus på spørsmål knyttet til hellige steder og sameksistensutfordringene i Jerusalem.

Mellomkirkelig råd er ikke selv aktive i misjonsarbeid, men gir noe økonomisk støtte til Den palestinske lutherske kirken. Videre står Mellomkirkelig råd på en klar folkerettslig linje som vist i uttalelser i etterkant av Den andre intifadaen, den israelske invasjonen av palestinske byer $\mathrm{i}$ 
2002, og byggingen av separasjonsbarrieren på okkupert palestinsk område. Mellomkirkelig råd arbeider også opp mot norske politiske myndigheter, gierne i samspill med andre kirkelige organer, som Kirkens Nødhjelp og Norges Kristne Råd. ${ }^{26}$

\section{Norges Kristne Råd}

Norges Kristne Råd ble etablert i I993. Med en medlemsmasse som omfatter pinsebevegelsen, katolikker, lutheranere og ortodokse, må rådet må forholde seg til ulike teologiske og politiske innstillinger. Det er derfor viktig å merke seg hva som faktisk er oppnådd i rådets arbeid for å synliggiøre de kristne palestinerne og bidra til refleksjon i kristne miljøer omkring Midtøsten. Hovedarbeidet var knyttet til den felleskristne feiringen av Kristi fødsel, Jubileum 2000. Gjennom salg av produkter fra Betlehem, hovedsakelig betlehemslys, fikk mange en bevissthetsøkning om palestinerne generelt og kristne palestinere spesielt. Det ble samlet inn midler i norske menigheter til to prosjekter: et skolebygg i Betlehem og et traumesenter i nabobyen Beit Sahour.

Norges Kristne Råd selv driver ikke misjon, og bortsett fra det arbeidet som skjedde rundt 2000 års-feiringen, foregår ikke humanitært arbeid. Norges Kristne Råd var en av ti kristne organisasjoner bak markeringen mot separasjonsbarrieren holdt på Jernbanetorget 19. desember 2005, som ble kritisert av Israelsmisjonen. Norges Kristne Råd fikk også kritikk for uttalelsen "Ikke murer, men broer" hvor rådet “... støtter oppfordringen til Israel om å rive muren." Dette var vanskelig å godta for mange ukritiske israelvenner.

Et utvalg innenfor Norges Kristne Råd, Norsk Teologisk Samtaleforum, har laget en studie med arbeidstittel "Israel og Palestina - en økumenisk utfordring". ${ }^{27}$ Studiet søker å etablere forståelse for hvordan de palestinske kirkenes kall til en rettferdig fred også må få betydning for vår bibellesning. De palestinske kirkene, med svært få unntak, er enige om at slutt på okkupasjonen er avgiørende for en rettferdig fred. ${ }^{28}$

\section{Et lite blikk utover}

Siden dette temanummeret handler om Norden i Midtøsten, vil sentrale tendenser i andre nordiske land gjennomgås. Det kan ikke gis en like dekkende beskrivelse av disse landene, men jeg vil sammenligne tilnærmingen hos noen sentrale organisasjoner med de norske organisasjonene som allerede er omtalt.

I Sverige har det lenge vært sterk kontakt med kirkene i Midtøsten. Svenska Kyrkan har både en prest som bistår den palestinske lutherske biskopen, og et eget studiesenter i Jerusalem, Svenska Teologiska Institutet, hvor dialog med muslimer blir stadig mer framtredende. Videre har Svenska Kyrkan spilt en aktiv rolle i Hoppkampanjen (Häv Okkupationen av Palestina). Denne kampanjen har opplevd betydelig kritikk, blant annet fra jødiske ledere i Sverige. Kampanjen er koordinert av Sveriges Kristna Råd, og noen av frikirkene er også direkte medlemmer.

Videre har Diakonia, de svenske frikirkenes bistandsorgan, et omfattende engasjement med et eget internasjonal humanitærrett-program i det palestinske området. Frikirkene startet sitt eget studiesenter i Jerusalem, Swedish Christian Study Centre, siden Svenska Teologiska Institutet ble oppfattet å være for opptatt av et godt forhold til Israel. Dette oppfattet de 
svenske frikirkene å være et dårlig utgangspunkt for religionsdialog. De svenske kirkesamfunnene er enda mer kritiske til okkupasjonen enn de norske kirkene. Dette gjelder særlig de svenske frikirkene som ikke skiller seg merkbart fra Svenska Kyrkan.

Danmark er preget av at Folkekirkens Nødhjelp har hatt et klart standpunkt i konflikten, men opplever i liten grad å få støtte fra de etablerte kirkeorganene. Eksempelvis hadde Folkekirkens Nødhjelp en markering mot muren under Roskildefestivalen i 2004, ved å reise en åtte meter høy mur. Reaksjonene som kom bidro til at fokuset skiftet til å omhandle palestinske bønders tilgang til sine åkrer. I en påfølgende kampanje bidro enkeltpersoner med økonomiske midler for å støtte dyrkingen og høsting av oliventrær. Selv om det i Danmark naturligvis finnes organisasjoner som kan kategoriseres som ukritiske israelvenner, er det vanskelig å si at det er disse som dominerer i det kirkelige landskap.

Finland er preget av relativt stort innslag av ukritiske israelvenner blant de kristne, i kanskje større grad enn for de andre nordiske land. Interessant nok opererer Det finske misjonsselskap et relativt stort program fra Jerusalem, i tillegg til at Finland, på linje med de andre nordiske land, har $\sin$ egen spesifikke Israelsmisjon. Nærværet av FinnChurchAid er derimot mye mer beskjedent enn for de andre nordiske land. Konklusjonen er derfor at Finland er det landet som kanskje overgår Norge hva gjelder støtte til organisasjoner som oppfattes å fremme Israels interesser.

\section{Konklusjoner}

Den trenden som kan klarest avleses, er at det sterke israelvennskapet som preget de norske kristne menighetene og organisasjonene i årene umiddelbart etter opprettelsen av staten Israel, nå er blitt mer fasettert. Dette skyldes at den israelske okkupasjonen og okkupasjonspolitikken er blitt erkjent å være en avgjørende hindring for en rettferdig fred av etablerte kirkelige organer og organisasjoner. Stadig flere ser at internasjonal rett gir en bedre basis for å finne varige løsninger enn en bokstavelig forståelse av løsrevne bibeltekster. Samtidig er det kommet en rekke nye organisasjoner som er både ukritiske israelvenner og til dels kristensionistiske.

Det understrekes at de kirkesamfunnene og kristne organisasjonene som nå velger å støtte staten Israel, uansett hva myndighetene måtte foreta seg, bidrar indirekte til å svekke de lokale palestinske kirkene i det okkuperte palestinske området. Okkupasjonen er hovedgrunnen til at de kristne har vært de fremste til å emigrere, selv om også andre forhold spiller inn. Kristne, ukritiske israelvenner står derfor dessverre i en direkte interessemotsetning til de lokale palestinske kirkene.

De som støtter Israel uansett hva politiske og militære myndigheter foretar seg, gjør Israel en bjørnetjeneste. De som kritiserer Israel - på grunnlag av internasjonal lov - kan kanskje være til større hjelp for å få Israel til å legge om kursen, både overfor palestinerne og resten av verdenssamfunnet. Okkupasjonen skader også israelerne, siden okkupasjonen er med på å hindre at israelere kan leve i fred med sine naboer.

For å illustrere at ensidighet ikke er av det gode, vil jeg gjengi en uttalelse fra den lutherske presten i Beit Jala, Jadallah Shihadeh: "Hvis du vil giøre noe godt for Israel, legg alt inn på å gjøre noe godt for 
palestinerne. Hvis du vil gjøre noe godt for Palestina, legg alt inn på å gjøre noe godt for israelere." Dette mottoet kan kanskje framstå som noe naivt. Jeg tror det ligger mye i dette mottoet og at altfor mange kristne organisasjoner glemmer dette.

\section{$\cdot f \cdot$}

I Haugen, H.M. 2006: "Når religion blir politikk: Kristensionisme i USA og Norge”, i Kirke og Kultur Årg. III, nr 4 (under utgivelse).

2 En av dem som har skrevet mest begeistret om Israel i lys av de bibelske profetier og landløfter er biskop emeritius i Den norske kirke, Erling Utnem.

3 Metodistkirken var også med fra starten, men har senere trukket seg som følge av uenighet om profil. Etter hvert har fire andre kirkesamfunn kommet til: Baptistkirken, Det Norske Misjonsforbund, Den Evangelisk-Lutherske Frikirke og De Frie Evangeliske Forsamlinger. Baptistkirken, Det Norske Misjonsforbund, Den EvangeliskLutherske Frikirke, De Frie Evangeliske Forsamlinger og Israelsmisjonen.

4 Se URL: www.hjhome.org

5 Et eksempel er at kristensionister ofte vises til den første delen av I Mos I2.3 ("Jeg vil velsigne dem som velsigner deg og forbanne dem som forbanner deg") uten å ta med den siste delen av dette verset ("I deg skal alle slekter på jorden velsignes").

6 Skarsaune, O. I994: «Israels venner: Norsk arbeid for Israelsmisjonen I844-I930», Oslo: Luther forlag, s. 49

7 Solheim, M. I986: «Nybrott: 27 år i Israel - eit attersyn», Den Norske Israelsmisjon/Luther forlag, s. 64-65.

8 Den siste reaksjonen kom etter en markering utenfor Julekrybben til Kirkens Bymisjon på Jernbanetorget I9. desember 2005: "Smakløs kirkelig Midtøstendemonstrasjon"; URL: http://www.israelsmisjonen.no/ php/visArtikkel.php?id=94.

9 Den Norske Israelsmisjons Strategi- og langtidsplan 2005-07, s. 9.

IO Ibid, s. 20.

II Ordet og Israel og Stiftelsen for Bibelen og Israel. Også Ordet og Israel snakker om "Guds frelsesplan for Israel og folkene.” (Ordet og Israels Lov, paragraf 3d); se URL: http://www.ordetogisrael.no). Stiftelsen for Bibelen og Israel er drevet av Gro Wenske (tidligere Faye-Hansen), og utgir bladet Israels røst.

I2 Samtale med Generalsekretær i Den Norske Israelsmisjon, Rolf Gunnar Heitmann, I2. juni 2006.

I3 Dagens Næringsliv: “Israels beste venner', s. 36-4I, 29.30. juli 2006 .

I4 Det er ikke vanlig å regne de ulike kristne senter- menighetene (en av de største er Levende Ord i Bergen) som pinsevenner.

I5 Fra Sjibbolet årg. 59 april/mai 2006, s. 3, punktene 6 og 7.

I6 Ibid, s. I5.

I7 Ecumenical Accompaniment Programme for Palestine and Israel (EAPPI).

I8 For Kirkens Nødhjelp er det sentralt at en bygging av en slik barriere på israelsk territorium ikke ville vært folkerettsstridig.

I9 Se Fyllingsnes, E. 2005: "Anti-semittisme som aktuell utfordring” i Ung Teologi, Årg. 28, Nr 2, s. 43-56. Se også pressemelding fra Rådsmøtet i Israelsmisjonen, fotnote viii.

20 Rådet består av 20 medlemmer: II fra bispedømmene, en fra Bispemøtet, en fra Kirkens Nødhjelp, en valgt på fritt grunnlag, en valgt fra Kirkerådet, tre som representerer Den norske kirke i de sentrale internasjonale kirkelige organene (Kirkens Verdensråd, Det lutherske verdensforbund og Konferansen av europeiske kirker), samt lederne i fagnemndene Teologisk Nemnd og Komiteen for Internasjonale Spørsmål.

2I Evangelical-Lutheran Church in Jordan and the Holy Land (ELCJHL)

22 Biskop Ole Chr. Kvarme, som arbeidet for Israelsmisjonen i Haifa og Jerusalem i årene I976-85, spilte her en sentral rolle.

23 Statement on the Status of Jerusalem; URL: http://www.wcc-coe.org/wcc/what/international/ state2o.html.

24 For vedtaket, se: URL: http://www.eappi.org/pressreleas esen.nsf/index/pr-cc-05-08.html. For en forklaring av vedtaket, se: URL: http://www.wcc-coe.org/wcc/what/interna tional/regconcerns-palestine-israel-ccminute.html. For en mer omfattende analyse av de ulike tiltakene, se Haugen, H.M. 2006: "Israels okkupasjon og kirkene - Rett til å kritisere - og deinvestere?’, i Kirke og Kultur Årg. III Nr 3, s. 43I-450.

25 Sak MкR 39/05: 'Investeringer og handel: Vestbredden'; URL: http://www.kirken.no/besluttende_organer/ nyhet Det.cfm?pNyhetId=789\&pNyhetKat $=5 \& p$ VedtakId $=I 73$.

26 Som eksempel, se brevet "Vedrørende invasjonen i Gaza"; URL: http://www.nca.no/article/articleview/6I64.

27 Dette studiedokumentet vil bli lansert Io. oktober 2006.

28 Det finnes kristne palestinere som står for en kristensionistisk innstilling, men disse er ikke aksepterte blant de andre kirkene. Se den palestinske baptistpastoren Naim Khoury, som uttalte om tilbaketrekningen fra Gaza: "From a biblical perspective, I believe Israel should not have left that area." uRL: http://www.israeltoday.co.il/ Default.aspx?tabid $=\mathrm{I} 28 \&$ view $=\mathrm{item} \& \mathrm{idx}=703$. 